\title{
India and Foreign Institutional Investors
}

\author{
Girisha M C \\ Head of the Department, Govt First Grade College (Affiliayed To University Of Mysore) Periyapattna \\ 571107 Karnantaka
}

\begin{abstract}
Developing countries are no strangers to financial crises. The proclivity to crisis and to financial boom-bust cycles was especially evident in more financially open and deregulated developing economies. It is now well known that financial liberalization has resulted in an increase in financial fragility in developing countries, making them prone to periodic financial and currency crises, not just internal banking and related crises, and currency crises stemming from more open capital accounts. Greater freedom to invest, including in sensitive sectors such as real estate and stock markets, ability to increase exposure to particular sectors and individual clients and increased regulatory forbearance all lead to increased instances of financial failure. In addition, the emergence of universal banks or financial supermarkets increases the degree of entanglement of different agents within the financial system and increases the domino effects of individual financial failures.

The global economic and financial situation is recovering slowly. The large fiscal deficits and high debt ratios coupled with slow economic growth have created unsettling conditions for business and have potential for causing great volatility in financial markets. It is hard to visualize strong economic growth in the advanced economies in 2010 and to a large extent in 2011.

The implications of this, for India's strategy to return to the 9.0 per cent growth trajectory, are that public policy must promote business confidence and facilitate increased investment.This paper is focusing on the role of Foreign Institutional Investors on Indian economy.

Key words - currency, crisis, economy, investment,
\end{abstract}

\section{Introduction}

Global growth is slowing down again, after a contraction in 2009 and a recovery in 2010. The euro area appears headed for recession. A slowing global economy will continue to drag domestic recovery in 2012-13. However, available information suggests that in spite of a dip in growth, the world economy is unlikely to enter another recession.

Growth in India is moderating more than was expected earlier. It is likely to be below potential during 2011-12, but is expected to recover at a modest pace in 2012-13. The slack in investment and net external demand components of aggregate demand may keep the pace of recovery low. Inflation has started to fall, broadly in line with the projected trajectory. Nonetheless, price pressures remain, with risks emanating from suppressed domestic energy prices, the incomplete pass-through of rupee depreciation and slippage in fiscal deficit. The decline in food inflation is likely to reverse ahead with the waning of base effects and seasonal factors behind the fall.

The growth slowdown, high inflation and currency pressures, complicate policy choices. While monetary policy's main goal is to maintain low and stable inflation, it also has to take into account the downturns in growth for possible counter-cyclical responses. These responses need to factor in the overall macro-economic situation, including fiscal and current account gaps. So, while the course of monetary policy ahead will be largely calibrated and shaped by the evolving growth-inflation dynamics, the impact of other macro-variables would have to be considered as they condition these dynamics.

\section{Foreign_institutional_investors:}

In this globalised age significant amount of capital is invested into developing economies from developed world. Significant amount of these investment are bought to developing economies by the way of portfolio investments by foreign institutional investors (FII).

Foreign institutional investors have gained a significant role in Indian capital markets. Availability of foreign capital depends on many firm specific factors other than economic development of the country. In this context this paper examines the contribution of foreign institutional investment particularly among companies included in sensitivity index (Sensex) of Bombay Stock Exchange. Also examined is the relationship between foreign institutional investment and firm specific characteristics in terms of ownership structure, financial performance and stock performance. It is observed that foreign investors invested more in companies with a higher volume of shares owned by the general public. The promoters' holdings and the foreign investments are inversely related. Foreign investors choose the companies where family shareholding of promoters is not 
substantial. Among the financial performance variables the share returns and earnings per share are significant factors influencing their investment decision..

Since 1990-91, the Government of India embarked on liberalization and economic reforms with a view of bringing about rapid and substantial economic growth and move towards globalization of the economy. As a part of the reforms process, the Government under its New Industrial Policy revamped its foreign investment policy recognizing the growing importance of foreign direct investment as an instrument of technology transfer, augmentation of foreign exchange reserves and globalization of the Indian economy. Simultaneously, the Government, for the first time, permitted portfolio investments from abroad by foreign institutional investors in the Indian capital market. The entry of FIIs seems to be a follow up of the recommendation of the Narsimhan Committee Report on Financial System. While recommending their entry, the Committee, however did not elaborate on the objectives of the suggested policy. The committee only suggested that the capital market should be gradually opened up to foreign portfolio investments.

\section{Regulations:-}

(a)Foreign Institutional Investors (FIIs) are allowed to invest in the primary and secondary capital markets in India through the portfolio investment scheme (PIS).

(b)Under this scheme, FIIs can acquire shares/debentures of Indian companies through the stock exchanges in India.

The ceiling for overall investment for FIIs is $\mathbf{2 4}$ per cent of the paid up capital of the Indian company.

The limit is 20 per cent of the paid up capital in the case of public sector banks, including the State Bank of India.

The gross purchases of debt and equity by FIIs increased by 37.7 percent to Rs.8,46,438 crore in 2009-10 from Rs.6,14,579 crore in 2008-09.

The combined gross sales by FIIs increased by 6.6 percent Rs.7,03,780 crore from Rs.6,60,389 crore during the same period in previous year.

The total net inflow of FII was Rs.1,42,658 crore as against an outflow of FII was Rs.45,811 crore in 2008-09.

During 2009-10, there was a net inflow in the equity segment by FIIs amounting to Rs.1,10,220 crore.

FII poured a net Rs.1,42,658 crore in Indian markets.

Month-wise, the net FII inflow was the highest in equity segment in May 2009 (Rs.20,017 crore) followed by March 2010 (Rs.19,928 crore) and September 2009 (Rs.18,344 crore).

The FIIs were permitted to trade in the derivatives market in February 2002.

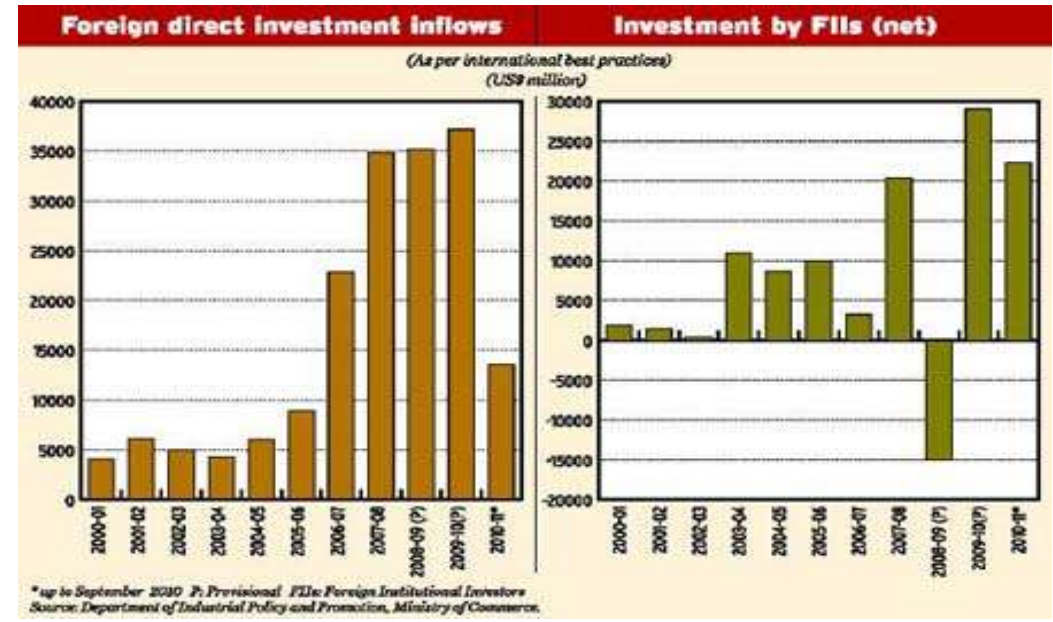

Foreign Direct Investment (FDI) and Foreign Institutional Investment are the investment done in the foreign country. FDI is an investment made by a father country in a foreign country, where as, FII is the investment done by any investor on the makers of foreign country.

In FII, only the company registration is needed in the stock exchange in order to make investments but FDI has very different criteria to be fulfilled to make an FDI investment. People also say the hot burning money to foreign Institutional Investment because the FII investor has liberty to withdraw to sell at any time, but same thing is not possible in Foreign Direct Investment (FDI). In a simpler word, we can say that, it is very easy to enter the stock market through Foreign Institutional Investment where as, things are not easier in Foreign Direct Investment. FDI is highly preferred to the FII as they are considered to be the most beneficial kind of foreign investment for the whole economy of the nation. This is the actual reason for which nations choose FDI's more than FIIs. 
Foreign Direct Investment (FDI) flows into a company's assets, fuels production, employment, taxes and growth, etc. Where as Foreign Institutional Investment (FII) flows into the secondary market, that is, stock exchanges. While both are important, FDI has a special importance for a developing country such as India. The FIIs, has added depth and substance stock market.

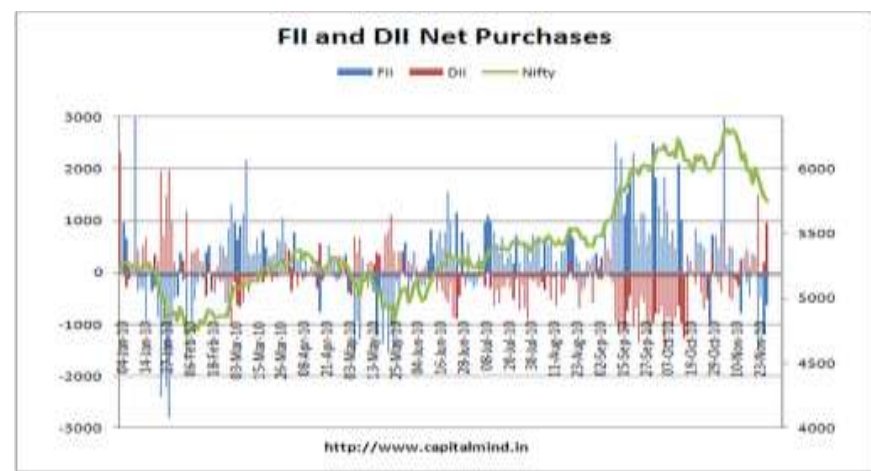

Foreign investors seem to have reduced their allocations to India in the last few days as they withdraw funds from the market. From June they've only been investing more into the market, and September's seen massive inflows. The outflows are not much - just 3,500 crores this week.

In November the Nifty is down about 4\% (From 6000 down to 5750) and FIIs still have a net positive investment of 4,400 crores for the month. The cumulatives (to smoothen out small issues) is positive at the 120 day level, but is starting to go down at the 20 day cumulative.

Historically this isn't much of an indicator, except that: On nearly every intermediate dip in the last three-four years, we have seen the FII 20-day cumulative goes below zero before a recovery happens.

Continued FII negativity may be a result of the European Debt Crisis, but it will be quite negative for India because much of the recent move has been because of FII money coming in. Of course, a massive rescue attempt in Europe is a big positive for our markets. Combined with the QE2 in the US, that will be a huge impact. But there is one point at which no more rescues will be possible or palatable.

\section{Depreciation of Indian Rupee 2012}

Volatility in the exchange rate is increasingly being recognized as a concern for the Indian economy. After maintaining a range bound movement in Q1 FY12, the rupee has registered depreciation against the dollar since August 2011. The question being raised is whether this trend will be reversed or has volatility come to stay in this market?

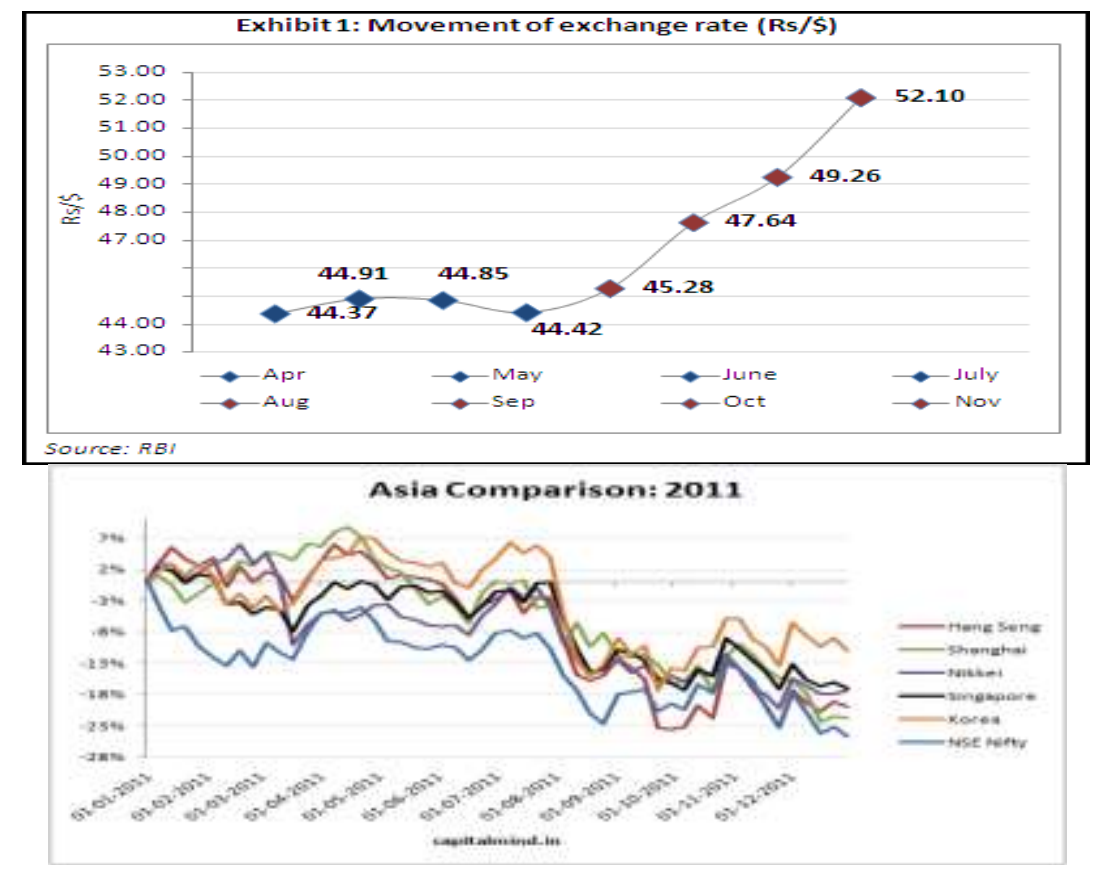




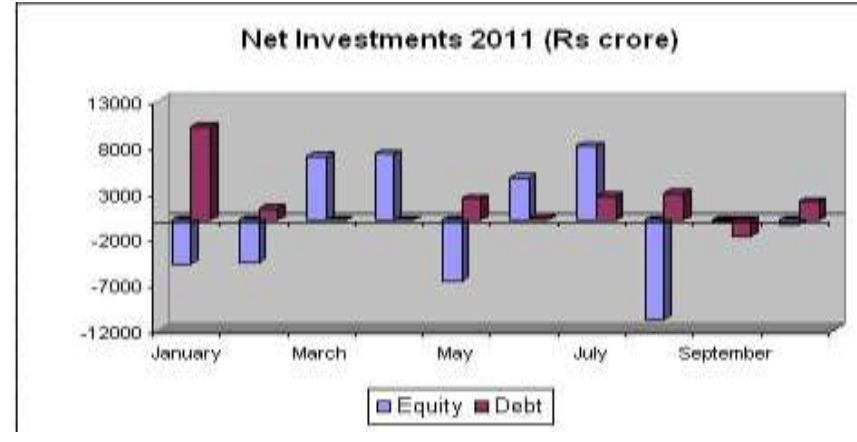

Whatever the causes, the impact on the domestic stock market has been sharp and direct. Since the Indian stock market is still relatively shallow, and FII activities play a disproportionately strong role in determining the movement of the indices, it is not surprising that this outward flow has been associated with the overall decline in stock market valuations.

When the crisis first broke internationally, within India there was much talk of how the Indian economy is less likely to be affected and how the Indian financial sector will be relatively immune to the winds from the international financial implosion. But it is clear that important elements of the balance of payments and the domestic financial sector have been affected. There are significant implications for domestic banking, which are already reflected in the credit crunch that has dramatically affected access to credit especially for small and medium enterprises. There are effects on some important macroeconomic prices - in particular the exchange rate. And there are direct and indirect effects on employment, with falling export employment generating negative multiplier effects.

\section{Recommendations}

After the analysis of the project study, following recommendations can be made:

1) Simplifying procedures and relaxing entry barriers for business activities and providing investor friendly laws and tax system for foreign investors.

2) Allowing foreign investment in more areas. In different industries indices the FIIs should be encouraged through different patterns like futures, options, etc.

3) Somewhere, a restriction related to the track record of Sub- Accounts is also to be made on the investors who withdraw money out of the Indian stock market who have invested with the help of participatory notes.

4) We have to modernize and also have to save our culture. Similarly the laws should be such that it protects domestic investors and also promote trade in country through FIIs.

\section{Conclusion:}

FII are the important variable to Indian economy, they directly affect the wealth created Indian economy. In recent period FII impacted the economy in adverse way. It is observed that FII affected on Indian stock market \& value of rupee against us $\$$.

It is more than obvious that the current global crisis provides a real opportunity to initiate and develop alternative policies, both internally and domestically. A change in economic paradigm is essential; without it the international economy will continue to lurch from crisis to crisis and the developing world will not be able to advance and provide basic needs to citizens. The need for more state intervention in economies is now recognized everywhere. The concern now is to ensure that such state involvement is more democratic and more accountable to the people.

\section{References:}

[1] Akyuz, Yilmaz (2008) "The global financial crisis and developing countries",

[2] Chandrasekar, C. P. (2008b) "India's sub-prime fears" Economic and Political Weekly

[3] Misra Puri (2011) "Indian economy"

[4] Madhu Vij (2010) "International Financial Management"

[5] www.rbi.org.in

[6] www.fema.org.in

[7] Intrnational Economics $5^{\text {th }}$ edition- Francis Cherunlam

[8] www.fipbindia.com/

[9] dipp.nic.in/fdi_statistics/india_fdi_index.htm 